\title{
Plasminogen binding by oral streptococci from dental plaque and inflammatory lesions
}

Correspondence
Bertil Kinnby
Bertil.Kinnby@od.mah.se

Received 14 September 2007

Revised 20 December 2007

Accepted 21 December 2007

\author{
Bertil Kinnby, ${ }^{1}$ Nuala A. Booth ${ }^{2}$ and Gunnel Svensäter ${ }^{1}$ \\ ${ }^{1}$ Department of Oral Biology, Malmö University, S-20506 Malmö, Sweden \\ ${ }^{2}$ Institute of Medical Sciences, University of Aberdeen, Aberdeen AB25 2ZD, UK
}

\begin{abstract}
Plasminogen binding by bacteria is a virulence factor important for the entry and dissemination of bacteria in the body. A wide variety of bacteria bind plasminogen, including both organisms causing disease and components of the normal oral flora. The purpose of this study was to examine the characteristics of plasminogen binding by six clinical isolates of oral streptococci from both dental plaque and inflammatory lesions. All the strains bound plasminogen with approximately the same affinity, and binding was specific and lysine-dependent as evidenced by its inhibition by $\varepsilon$-aminocaproic acid. All of the test strains were capable of activating bound plasminogen to plasmin without the addition of a plasminogen activator, and subsequent analysis revealed the presence of streptokinase in all strains. However, the streptococci exhibited fibrinolytic activity only in the presence of plasminogen and this could be inhibited by the addition of $\varepsilon$-aminocaproic acid. SDS-PAGE and 2D gel electrophoresis coupled with plasminogen ligand blotting showed that only a subset of the total proteins (2-15) were involved in the binding of plasminogen. Partial identification of the binding proteins revealed that four glycolytic enzymes, enolase, phosphoglycerate kinase, glyceraldehyde-3-phosphate dehydrogenase and phosphoglycerate mutase, were predominant in binding plasminogen. The binding of plasminogen by bacteria from pus did not differ from that of the strains from supragingival plaque. The findings illustrate how apparently innocuous commensal bacteria are capable of utilizing a mechanism that is generally regarded as being of importance to pathogenicity and suggest an additional role of plasminogen binding.
\end{abstract}

\section{INTRODUCTION}

The activation of plasminogen to the highly tissuedestructive, broad-spectrum serine protease plasmin is the physiological process that results in the dissolution of blood clots. Plasmin is also instrumental in the migration of cells through tissues and is important for the proteolytic tissue breakdown associated with inflammation (Collen, 2001). The plasminogen activation (PA) system, which results in the formation of plasmin, is specifically activated by the plasminogen activators tPA (tissue plasminogen activator) and uPA (urokinase type), via cleavage of a peptide bond. These two activators are balanced by the specific inhibitors PAI-1 and PAI-2, while active plasmin is counteracted by the plasma proteins $\alpha$-2-antiplasmin and $\alpha$-2-macroglobulin. These activators and inhibitors can also be produced by inflammatory cells, such as macrophages and granulocytes, as well as by stationary tissue cells like fibroblasts and endothelial cells, which are activated in

Abbreviations: 2DE, two-dimensional polyacrylamide electrophoresis; CSP, cell-surface-associated proteins; GAPDH, glyceraldehyde-3-phosphate dehydrogenase; RP, released proteins; tPA, tissue plasminogen activator. inflammation. Plasminogen activation plays a central role in the breakdown of extracellular matrix (ECM), since plasmin can act directly on non-collagenous ECM proteins and indirectly by activating proforms of the metalloproteinases, which are specific for different connective tissue proteins (Lijnen, 2001). Thus, the plasma protein plasminogen represents an important proteolytic potential through this interaction between the PA system and other tissue-degrading systems.

A wide variety of micro-organisms are known to bind plasminogen to their surface, including bacteria causing serious diseases, such as Yersinia pestis, Borrelia burgdorferi (Coleman \& Benach, 2000), Streptococcus pyogenes (Walker et al., 2005) and Candida albicans (Crowe et al., 2003). Such binding and plasminogen activation is viewed as an important virulence property of these and other invasive infectious organisms. For example, the demonstration that Streptococcus pneumoniae with plasmin bound to the surface was capable of migrating through artificial basement membrane structures in vitro (Eberhard et al., 1999) indicates that surface-associated plasmin would facilitate tissue invasion through epithelial barriers, resulting in damage to superficial connective tissue structures. A 
second important virulence issue would be that, as any inflammation at the primary site of infection would induce fibrin formation in the tissue to wall off or encapsulate the infective agent, fibrin- and tissue-degrading bacteria might contribute to the enlargement of the primary lesion or spread beyond it to distant locations. Thus, the binding and activation of plasminogen can be seen as an important step in the dissemination of pathogens that cause plague, endocarditis and tick disease (Coleman et al., 1997). Furthermore, since plasminogen is a host protein, bacteria bound to it might be regarded as being 'host' and could, therefore, acquire increased virulence by being protected from the host immune reactions (Rudney \& Chen, 2006).

In addition to the overtly pathogenic bacterial species, plasminogen is also bound by bacteria belonging to the normal flora of the mouth, such as Streptococcus mutans (Jones \& Holt, 2004), Peptostreptococcus micros (Grenier \& Bouclin, 2006) and Fusobacterium nucleatum (Darenfed et al., 1999; Coleman \& Benach, 1999; Lottenberg et al., 1994). The bacteria colonizing the teeth are flooded by gingival crevicular fluid, a tissue transudate containing plasma proteins, as well as proteins produced and released in the local gingival tissue. The flow rate of crevicular fluid increases when the gingival tissues are inflamed and, as a consequence, both plasminogen activators and their inhibitors are found in high concentrations in gingival epithelium and fluid (Kinnby, 2002). Oral bacteria in dental and gingival plaque would therefore have the opportunity to bind plasminogen released from plasma and generate plasmin with the assistance of the locally produced plasminogen activator tPA (Kinnby et al., 1991). In addition, streptococci are known to produce streptokinase, a large molecule which by forming a complex with plasminogen causes a conformational change resulting in plasmin activity (Reddy \& Markus, 1972). However, there are no reports of oral streptococci producing streptokinase. A further interesting feature of the oral streptococci is their ability to enter into and survive within buccal epithelial cells (Rudney et al., 2005, Rudney \& Chen, 2006). Since such buccal cells will be desquamated, this process can be seen as a survival mechanism developed by these bacteria.

Plasminogen binding by oral bacteria in plaque might be involved in the pathogenesis of gingivitis and the progression of periodontitis by initiating or promoting the proteolytic destruction of oral tissues. Whether bacteria in biofilms on solid surfaces, such as supragingival plaque, would have need for such a property is not known. It is conceivable that the plasminogen-binding capacity might be a characteristic determining the ecological location of bacteria in the mouth, with bacteria found in inflammatory lesions having a more obvious need for plasminogen binding than bacteria in supragingival plaque. The objective of the present study was thus to determine the characteristics of plasminogen binding by various oral streptococci of the commensal flora isolated from fundamentally different locations in the mouth, and to ascertain the role of bacterial cell surface proteins in the binding process.

\section{METHODS}

Bacterial isolates and growth conditions. Three strains of streptococci isolated from dental plaque (Streptococcus anginosus $\mathrm{AA} 4, S$. anginosus $\mathrm{AB} 6, S$. oralis LA11) and three strains of streptococci from oral inflammatory lesions (S. anginosus 62, S. oralis $63, S$. oralis 20 ) were studied with regard to plasminogen binding and the characterization of plasminogen-binding proteins. In all cases, clinical isolates with a minimum number of transfers were used. Identification of the streptococcal strains was based on $g d h$ sequence, sodA sequence (Hoshino et al., 2005), inulin fermentation, arginine and aesculin hydrolysis, and haemolysis. The identity of $S$. anginosus was confirmed by $16 \mathrm{~S}$ rRNA sequence analysis and by demonstration of arginine and/or aesculin hydrolysis. The strains were grown on blood agar plates, with five colonies selected from each plate and cultured in $2 \mathrm{ml}$ Todd-Hewitt broth overnight. Aliquots of each suspension were transferred to $100 \mathrm{ml}$ Todd-Hewitt broth and incubated at $37{ }^{\circ} \mathrm{C}$ until they reached exponential phase (5-9 h), at which time the cultures were washed twice with $10 \mathrm{mM}$ Tris buffer ( $\mathrm{pH}$ 6.8) and the pellet frozen at $-20{ }^{\circ} \mathrm{C}$ until used in the kinetic studies and the assay of fibrinolytic activity.

Kinetic studies of plasminogen-binding capacity. We undertook to determine maximum binding capacity and binding affinity. Five samples of each of the six strains were employed in these kinetic assays. For this, the cell pellets were resuspended in $1.8 \mathrm{ml} 10 \mathrm{mM}$ PBS (7.2 mM K $\mathrm{HPO}_{4}, 2.8 \mathrm{mM} \mathrm{KH_{2 }} \mathrm{PO}_{4}, 150 \mathrm{mM} \mathrm{NaCl}, \mathrm{pH}$ 7.16) and adjusted to a cell concentration of $1 \times 10^{8} \mathrm{ml}^{-1}\left(\mathrm{OD}_{600} 0.6\right)$. Samples were plated in triplicate $(100 \mu \mathrm{l}$ per well) in 96-well polypropylene plates (Greiner 655201) and the cells were allowed to attach for $30 \mathrm{~min}$ at $37{ }^{\circ} \mathrm{C}$. After blocking with $3 \%$ BSA in $50 \mathrm{mM}$ carbonate/bicarbonate ( $\mathrm{pH}$ 9.6), the cells were incubated with human plasminogen $\left(0-50 \mu \mathrm{g} \mathrm{ml}^{-1}\right.$ ) (Enzyme Research Laboratories) for $30 \mathrm{~min}$ (Crowe et al., 2003). Cell-bound plasminogen was detected by incubating with horseradish-peroxidase-labelled rabbit antibodies against plasminogen (Dako) (1.3 $\mathrm{g}^{-1}$ antibody solution diluted $1: 2000$ in PBS with $1 \% \mathrm{BSA})$, for $3 \mathrm{~h}$ at room temperature followed by $15 \mathrm{~min}$ incubation with peroxidase substrate, Sigma FAST $o$ phenylenediamine dihydrochloride. The absorbance was then read at $450 \mathrm{~nm}$. For inhibition studies, $\varepsilon$-aminocaproic acid, at a final concentration of $10 \mathrm{mM}$, was added with plasminogen $(6-25 \mu \mathrm{g}$ $\mathrm{ml}^{-1}$ ) following the procedures described above. Background absorbance in cell-free wells was subtracted from all values and the binding affinity $\left(K_{\mathrm{d}}\right)$ and the maximum binding capacity $\left(B_{\max }\right)$ were determined. Experiments done in a concentration range enabling the plotting of a double-reciprocal graph were used for the calculation of $K_{\mathrm{d}}$ and $B_{\max }$. The median value for each sample was used in the statistical analysis, which was performed using GraphPad Prism version 4.00 for Macintosh (GraphPad Software, http://www. graphpad.com). The mean coefficient of variation for the triplicate values was $9 \%$.

Fibrinolytic activity of cell-surface-bound plasminogen. The functional activity of cell-bound plasminogen was studied by measuring fibrinolytic activity on agarose-supported fibrin plates.

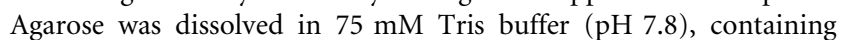
$22 \mathrm{mM} \mathrm{NaCl}$, boiled in a microwave oven for $30 \mathrm{~s}$ and allowed to cool to $44{ }^{\circ} \mathrm{C}$ before plasminogen-free fibrinogen (final concentration $2 \mathrm{mg} \mathrm{ml}^{-1} ; 6 \mu \mathrm{M}$ ) and thrombin (final concentration $0.06 \mathrm{U} \mathrm{ml}^{-1}$ ) were added. The mixture was then poured into plastic Petri dishes and allowed to set before wells were punched out. The previously prepared and frozen cell pellets were thawed and resuspended in PBS and then incubated at a concentration of $4 \times 10^{7}$ cells ml $^{-1}$ with plasminogen (final concentration, $160 \mu \mathrm{g} \mathrm{ml}^{-1}$ ) for $1 \mathrm{~h}$ at $37{ }^{\circ} \mathrm{C}$. Following incubation, the cells were washed three times with the Tris/ $\mathrm{NaCl}$ buffer to remove unbound plasminogen and resuspended at the same concentration in the same buffer, after which t-PA was added to 
a final concentration of $70 \mathrm{nM}$. For each assay, $20 \mu \mathrm{l}$ sample was added to each well and the fibrin gel plate was incubated for up to $24 \mathrm{~h}$ in a moist chamber at $37{ }^{\circ} \mathrm{C}$ to allow zones of lysis to appear. Control samples were devoid of either plasminogen, tPA, or cells. The extent of lysis generated by each organism on a plate was recorded as the mean of two perpendicular diameters of each lysis zone. The fibrin gel assays were performed in triplicate. The overall result for each organism is reported as the median of the values obtained from the three plates.

Preparation of released and surface-associated extracellular proteins. Each test strain of oral streptococci was grown to exponential phase in batch culture in PYG medium ( $\mathrm{pH} 7.0$ ) in an atmosphere of $10 \% \mathrm{H}_{2}, 5 \% \mathrm{CO}_{2}$ and $85 \% \mathrm{~N}_{2}$ and centrifuged at $2700 \mathrm{~g}$ for $20 \mathrm{~min}$ at $4{ }^{\circ} \mathrm{C}$. The supernatant containing released proteins (RP) extruded from the cells was concentrated by the addition of trichloroacetic acid to a final concentration of $10 \%$ and the resulting sample was incubated at $4{ }^{\circ} \mathrm{C}$ overnight. It was then centrifuged at $2700 \mathrm{~g}$ for $30 \mathrm{~min}$ at $4{ }^{\circ} \mathrm{C}$. The resulting pellet containing the TCA-precipitable proteins was dissolved in $1 \mathrm{ml}$ icecold acetone and sonicated for $3 \times 10 \mathrm{~s}$. The samples were then centrifuged at $16000 \mathrm{~g}$ for $30 \mathrm{~min}$ at $4{ }^{\circ} \mathrm{C}$ and the supernatant discarded. The resulting pellet was dissolved in $750 \mu \mathrm{l}$ twodimensional polyacrylamide electrophoresis (2DE) rehydration buffer [8 M urea, 2\% CHAPS, $10 \mathrm{mM}$ DTT, 2\% IPG buffer (Amersham Pharmacia Biotech)] and stored at $-20{ }^{\circ} \mathrm{C}$ until used in electrophoresis assays.

Cell surface-associated proteins (CSP) were isolated by washing the cell pellet twice in PBS followed by resuspension in $0.2 \% \mathrm{~N}$-decyl$\mathrm{N}, \mathrm{N}$-dimethyl-3-ammonio-1-propanesulfonate dissolved in PBS and incubation on a shaker ( 80 r.p.m.) for $1 \mathrm{~h}$ at $28{ }^{\circ} \mathrm{C}$, after which the samples were centrifuged at $6000 \mathrm{~g}$ for $10 \mathrm{~min}$ at $4{ }^{\circ} \mathrm{C}$. The supernatant containing the CSP was frozen until used in the electrophoresis assays.

Electrophoretic separation of the proteins in the RP and CSP samples. RP and CSP proteins were separated by SDS-PAGE, carried out according to procedures previously described (Chavez de Paz et al., 2005) with $10 \%$ polyacrylamide gels using the Mini Protean II electrophoresis system (Bio-Rad); each lane was loaded with $1 \mu \mathrm{g}$ protein for gels to be silver stained and with $20 \mu \mathrm{g}$ protein for gels to be ligand blotted. The RP were also separated by $2 \mathrm{DE}$, performed by the procedure of Svensäter et al. (2001). The isoelectric focusing was performed using the Multiphor II horizontal electrophoresis apparatus connected to a Multitemp II thermostatic circulator (Amersham Pharmacia Biotech). Immobiline DryStrip linear immobilized $\mathrm{pH}$ gradient (IPG) gel strips $(18 \mathrm{~cm}$ ) with a $\mathrm{pH}$ range of 4-7 (Amersham Pharmacia Biotech) were rehydrated in $330 \mu$ rehydration buffer containing the samples, which were allowed to absorb into the gel strips for $24 \mathrm{~h}$ in a reswelling cassette under silicone oil. The amount of sample loaded to each gel strip was adjusted to $20 \mu \mathrm{g}$ protein for gels to be silver stained and $70 \mu \mathrm{g}$ protein for gels to be ligandblotted. The proteins were focused at $15{ }^{\circ} \mathrm{C}$ under silicone oil using $150 \mathrm{~V}$ for $1 \mathrm{~h}, 300 \mathrm{~V}$ for $3 \mathrm{~h}, 600 \mathrm{~V}$ for $3 \mathrm{~h}, 1200 \mathrm{~V}$ for $12 \mathrm{~h}$ and $3500 \mathrm{~V}$ for $21 \mathrm{~h}$. After focusing, the IPG gel strips were frozen between plastic films at $-80{ }^{\circ} \mathrm{C}$ until equilibrated and embedded on top of $14 \%$ polyacrylamide gel, using $0.5 \%(\mathrm{w} / \mathrm{v})$ molten agarose. The SDS-PAGE was performed at constant current of $30 \mathrm{~mA}$ per gel overnight at $10{ }^{\circ} \mathrm{C}$. Proteins were visualized by silver staining according to the GE Healthcare silver staining protocol for proteins.

Ligand blotting with plasminogen. Following electrophoresis, the released proteins (RP) were transferred to nitrocellulose membranes at $25 \mathrm{~V}$ for $1 \mathrm{~h}$, at $6{ }^{\circ} \mathrm{C}$. After washing in PBS with Tween, the membranes were blocked with $3 \%$ BSA (Sigma) in PBS/Tween (BSA/ PBST) at $4{ }^{\circ} \mathrm{C}$ for $1.5 \mathrm{~h}$ at room temperature and ligand blotting was subsequently performed using human Glu-plasminogen (Enzyme Research Laboratories). The membranes were incubated in a $25 \mu \mathrm{g}$ $\mathrm{ml}^{-1}$ plasminogen solution (in $3 \% \mathrm{BSA} / \mathrm{PBST}$ ) for $2 \mathrm{~h}$ at room temperature, with bound plasminogen visualized with peroxidaselabelled rabbit antibodies against human plasminogen $\left(1.3 \mathrm{~g} \mathrm{l}^{-1}\right.$ diluted 1:7000 in 3\% BSA/PBST and incubated for $2 \mathrm{~h}$ at room temperature) followed by incubation with chemiluminescent peroxidase substrate ECL Western blotting substrate \#32106 (Pierce Chemical). To ensure that plasminogen binding to the protein bands was authentic, a control sample was prepared with plasminogen and its inhibitor $\varepsilon$-aminocaproic acid, while an additional control contained no plasminogen.

Western blotting against streptokinase. Following pretreatment as described above, the nitrocellulose membranes were incubated with rabbit antibody against streptokinase (Abcam \#35168; $2.5 \mu \mathrm{g} \mathrm{ml}$ in $5 \%$ BSA/TBST) for $2 \mathrm{~h}$ at room temperature. Visualization was performed with peroxidase-labelled goat-anti-rabbit antibody (Dako P0448) followed by incubation with chemiluminescent peroxidase substrate ECL Western blotting substrate \#32106 (Pierce Chemical).

Identification of proteins on 2D gels by mass spectrometry. Spots identified as plasminogen-binding proteins were cut from the gel and subjected to tryptic digestion and peptide mass fingerprinting. Mass spectrometry data were used to search the Mascot online database (http://www.matrixscience.com/) for identication of the proteins (Perkins et al. 1999).

\section{RESULTS}

\section{Plasminogen binding to oral streptococci}

The experiments on the binding of plasminogen to whole bacterial cells were done with fresh isolates of oral streptococci that were coated to microtitre plates. Dosedependent binding of plasminogen to whole cells was seen in all strains and the addition of $\varepsilon$-aminocaproic acid totally abolished binding. Fig. 1 shows a double-reciprocal plot of the plasminogen binding to S. oralis 63; the data for this strain were typical of those of the other test strains. The $K_{\mathrm{d}}$ and $B_{\max }$ values for plasminogen binding to whole streptococci are given in Table 1 . With the exception of $S$. oralis 20 , the values were in the same range, indicating that those strains were capable of binding a similar amount of plasminogen with a similar binding affinity.

\section{Fibrin lysis by cell-bound plasminogen}

Fibrinolytic activity by cell surface-bound plasminogen was detected in all the fresh isolates from pus and plaque when tested on preformed fibrin gels (Table 2); however, no correlation between the origin of the organism and the fibrinolytic activity was seen. Cell-free controls were negative. Controls without plasminogen were also essentially negative, which showed that the bacteria did not have any inherent fibrinolytic activity. However, assays without the added activator, tPA, also displayed fibrinolytic activity for all the strains studied. These results demonstrated that the cells possessed an inherent ability to produce plasmin-like activity from extracellular plasminogen without proteolytic activation by mammalian plasminogen activators. 


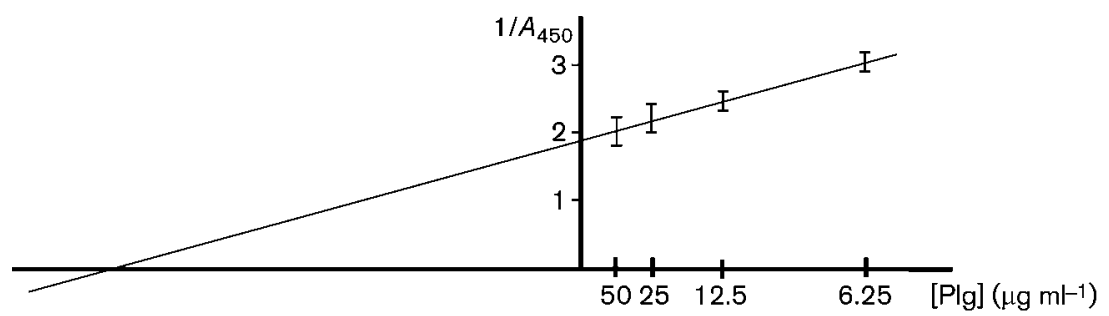

Fig. 1. Double-reciprocal plot showing kinetic analysis of the plasminogen binding of $S$. oralis 63.

\section{Western blotting against streptokinase}

Released proteins separated by SDS-PAGE and subjected to Western blotting showed bands reacting with antistreptokinase antibodies (Fig. 2) at the native size $47 \mathrm{kDa}$ and also, in most cases, bands compatible with the two major chymotryptic fragments of streptokinase, the $37 \mathrm{kDa}$ and $17 \mathrm{kDa}$ fragments (Medved et al. 1996).

\section{Analysis of surface-associated and extruded proteins}

Plasminogen capture by oral streptococci requires the presence of binding proteins at the cell surface, some of which may be readily released from the cells (RP), as well as those more tightly bound to the cell surface (CSP). Assayed separately by SDS-PAGE, silver-stained gels showed 20-30 TCA-precipitable RP released into the external medium by all the test strains (Fig. 3a). The CSP, released from the cell surface by propanesulfonate treatment, while fewer than those in the RP samples, were nevertheless significant in number (10-20; Fig. 3b).

Ligand blotting of extracellular RP transferred from the SDS-PAGE gels showed between 3 and 11 plasminogenbinding bands per strain, the majority of which were between 30 and $97 \mathrm{kDa}$ in size. Fewer plasminogenbinding bands were observed in the surface-associated CSP protein samples, the majority being between 46 and $66 \mathrm{kDa}$ in size. Both the RP and CSP protein samples showed differences between species as well as within species. That plasminogen binding was specific was demonstrated by the observation that no binding was seen in the absence of plasminogen, or following the preincubation of plasminogen with $\varepsilon$-aminocaproic acid, which

Table 1. Plasminogen binding to oral streptococci

The values are the means of at least three samples.

\begin{tabular}{|lcc|}
\hline Strain & $\boldsymbol{K}_{\mathbf{d}}(\mathbf{n M})$ & $\boldsymbol{B}_{\mathbf{m a x}}\left(\boldsymbol{A}_{\mathbf{4 5 0}}\right)$ \\
\hline S. anginosus 62 & 39 & 0.29 \\
S. anginosus AB6 & 40 & 0.37 \\
S. anginosus AA4 & 36 & 0.26 \\
S. oralis 63 & 41 & 0.53 \\
S. oralis 20 & 70 & 0.04 \\
S. oralis LA11 & 40 & 0.38 \\
\hline
\end{tabular}

blocks the lysine-binding sites that are responsible for the binding of plasminogen to other proteins.

2DE combined with ligand blotting with plasminogen was used to further resolve the plasminogen-binding proteins. Some bands in the SDS-PAGE gels corresponded to single spots on the 2DE gels (Fig. 4), such as those around 65, 75 and $90 \mathrm{kDa}$, while the 35 and the $55 \mathrm{kDa}$ bands were each resolved into two spots. In general 2-15 spots were involved in plasminogen binding, with obvious differences between species and strains. Comparison of the silverstained 2DE gels and the ligand blots in Fig. 4 reveals that only a small fraction of the proteins present were capable of binding plasminogen.

\section{Identification of proteins on 2D gels by mass spectrometry}

The major plasminogen-binding proteins were identified as glycolytic enzymes: enolase, phosphoglycerate kinase, glyceraldehyde-3-phosphate dehydrogenase (GAPDH), phosphoglycerate mutase, triosephosphate isomerase and 6-phosphofructokinase. As seen in Fig. 4(a), S. anginosus AA4 exhibited 11 plasminogen-binding proteins, some of which were these glycolytic enzymes. Strain 62 had only two binding proteins: enolase and phosphoglycerate mutase (Fig. 4b). S. anginosus AB6 and S. oralis 63 had 14 and 10 binding proteins, respectively, which included single proteins and multiple isoforms of the glycolytic enzymes. S. oralis LA11 and 20 had 10 and 8 plasminogenbinding proteins, respectively, with enolase binding in both strains. Generally, enolase was the strongest binder of the four glycolytic enzymes.

Table 2. Fibrinolytic activity by six strains of oral streptococci Mean values $(\mathrm{mm} \pm \mathrm{SD})$ of three assays are shown. Controls lacked plasminogen (Plg) or t-PA.

\begin{tabular}{|lccc|}
\hline & No Plg, +t-PA & + Plg, no t-PA & + Plg, +t-PA \\
\hline S. anginosus AA4 & 2 & $14 \pm 1.2$ & $12 \pm 1.5$ \\
S. anginosus 62 & 2 & $13 \pm 0.6$ & $13 \pm 0.6$ \\
S. anginosus AB6 & 0 & $16 \pm 0.5$ & $14 \pm 1.5$ \\
S. oralis 63 & 0 & $16 \pm 0.3$ & $13 \pm 1.8$ \\
S. oralis 20 & 3 & $14 \pm 2.0$ & $12 \pm 0.5$ \\
S. oralis LA11 & 3 & $14 \pm 1.0$ & $13 \pm 1.2$ \\
\hline
\end{tabular}




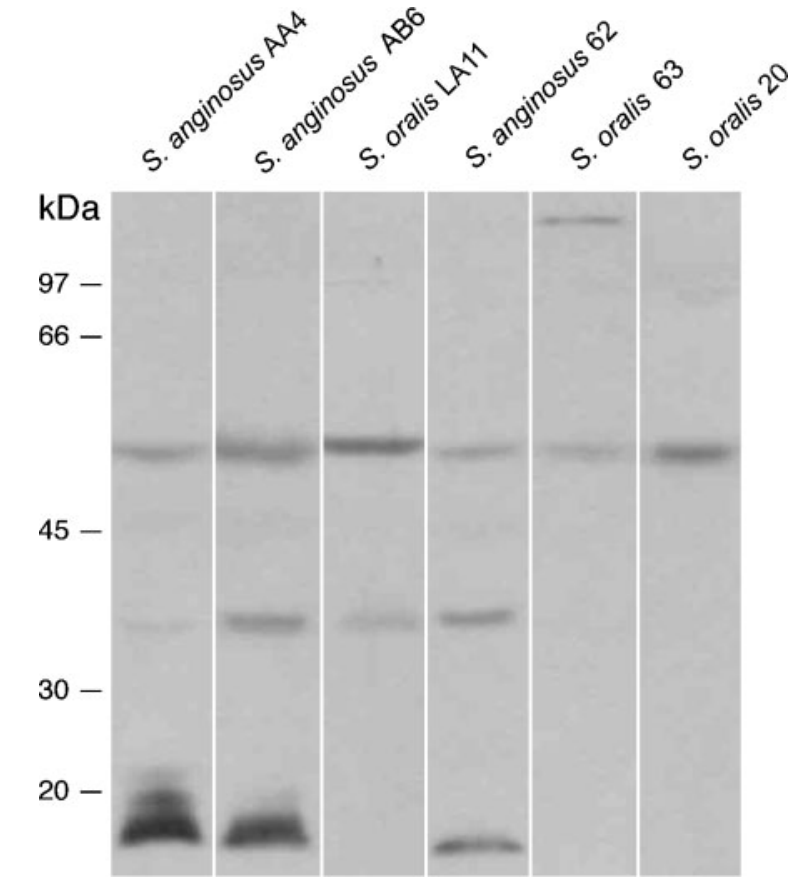

Fig. 2. Western blotting with anti-streptokinase on SDS-PAGEseparated released proteins from six strains of oral streptococci.

\section{DISCUSSION}

Through its ability to degrade all non-collagenous extracellular matrix molecules, plasmin is a readily avaliable tool for migrating cells in physiological, as well as pathological situations. Thus, it has been natural to study plasminogen binding as a possible microbial virulence mechanism and plasmin has been shown to be of great importance in the pathogenesis of serious invasive infections caused by micro-organisms such as group A streptococci ( $\mathrm{Li}$ et al., 1999; Khil et al., 2003; Sun et al., 2004) and Yersinia pestis (Titball \& Oyston, 2007; Degen et al., 2007). As a consequence of the focus on the highly pathogenic bacteria, little is known about plasminogen binding by members of the commensal flora. The bacteria that were the subject of this study were chosen because all were non-pathogenic components of the normal oral flora and thus would be expected to display characteristics different from pathogenic and invasive bacteria. In order to maintain their in vivo characteristics as much as possible and to reduce the possibility of artefactual changes in cell properties, all strains were clinical isolates subjected to a minimum of number of laboratory transfers.

The plasminogen-binding studies showed that all strains bound plasminogen to whole intact cells in a dosedependent manner. Except for S. oralis 20, the maximum binding values were similar $(0.26-0.53)$. The reason for the low $B_{\max }$ value for $S$. oralis 20 is unknown, but the result was a consistent characteristic of the organism. The plasminogen-binding affinity values $\left(K_{\mathrm{d}}\right)$ were also similar, ranging from 35 to $70 \mathrm{nM}$, which is about one-fifth of the $K_{\mathrm{d}}$ values reported for the opportunistically pathogenic commensal fungus Candida albicans (Crowe et al., 2003). In that study, it was also observed that a non-pathogenic yeast strain was capable of binding plasminogen with the same affinity as C. albicans, suggesting that the plasminogen binding per se may not be a general virulence factor. While binding affinity is important, a variety of other factors associated with plasminogen activation have to be considered. Physiological plasminogen activation normally takes place on a cell or fibrin surface, with binding to surface receptors dependent on interaction via lysine residues in the plasminogen molecule found in the so-called kringle domains (Plow et al., 1995). In the present study, the addition of the synthetic inhibitor $\varepsilon$-aminocaproic acid totally abolished the binding of plasminogen to the test bacteria, demonstrating that binding was lysine-dependent.

The SDS-PAGE gels showed that only a small fraction of all the proteins detected by silver staining were capable of binding plasminogen; we therefore employed proteomics to identify these plasminogen-binding proteins. $2 \mathrm{DE}$ analysis indicated that several of the plasminogen-binding bands on the SDS-PAGE gels were resolved into multiple spots. These were of varying strength, but generally two to four spots dominated. Mass spectrometric analysis showed that the isozymes of enolase were the most significant in all strains assayed. Another glycolytic enzyme that has previously been described as a plasminogen-binding protein is GAPDH (Lähteenmäki et al., 2005), which was found to bind strongly only in $S$. oralis LA11, while plasminogen was bound strongly to phosphoglycerate kinase in S. anginosus AA4, but not in the other organisms. The mass spectrometric identification of proteins corresponded well with previous data (Wilkins et al., 2003; Welin et al., 2004). These glycolytic enzymes have previously also been found extracellularly in S. pneumoniae (Ling et al., 2004), S. mutans (Hasona et al., 2007), group B streptococci (Hughes et al., 2002) and S. pyogenes (Cole et al., 2005).

Previous studies have shown that group A streptococci bind plasminogen by four surface receptors: group A streptococcal M-like protein, enolase, GAPDH and most recently PAM-related protein Prp (Pancholi \& Fischetti, 1998; Winram \& Lottenberg, 1998; Walker et al., 2005; Sanderson-Smith et al., 2007). Enolase and GAPDH are known to contain lysine residues (Derbise et al., 2004) and are, therefore, efficient binders of plasminogen. Such plasminogen binding to a lysine-containing receptor induces a conformational change that opens the plasminogen molecule to an extended form, which is not only more prone to activation, but is also protected from inhibition by the physiological plasmin inhibitor $\alpha_{2}$-antiplasmin (Castellino \& Violand, 1979).

A higher number of plasminogen-binding bands were seen in the samples of the extracellular proteins released from the cells than in those extracted from the cell surface by 
(a)
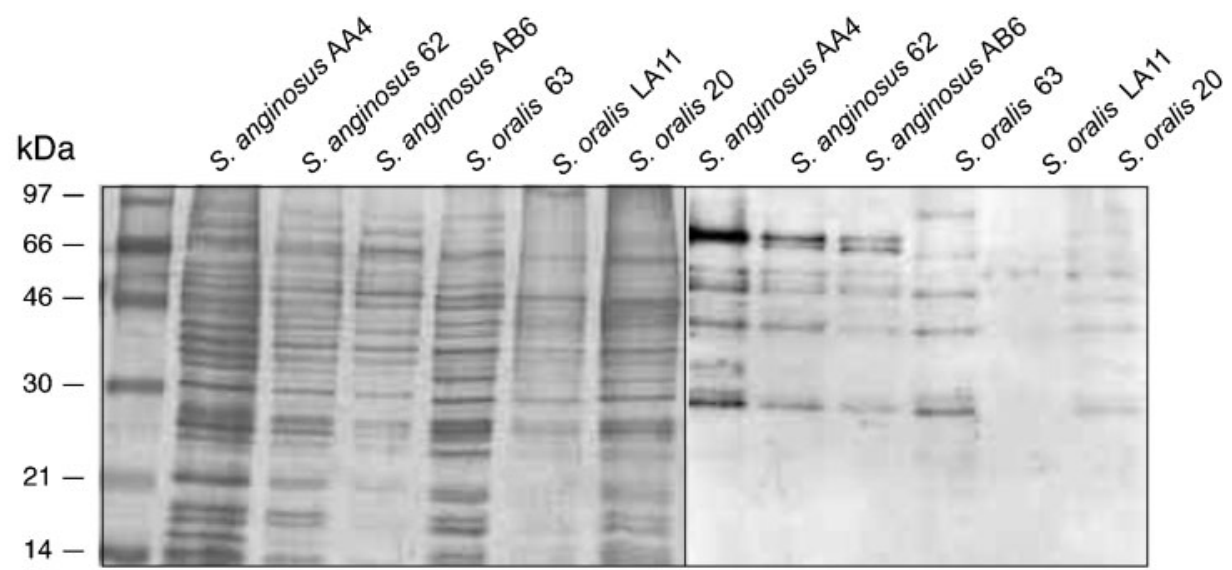

(b)

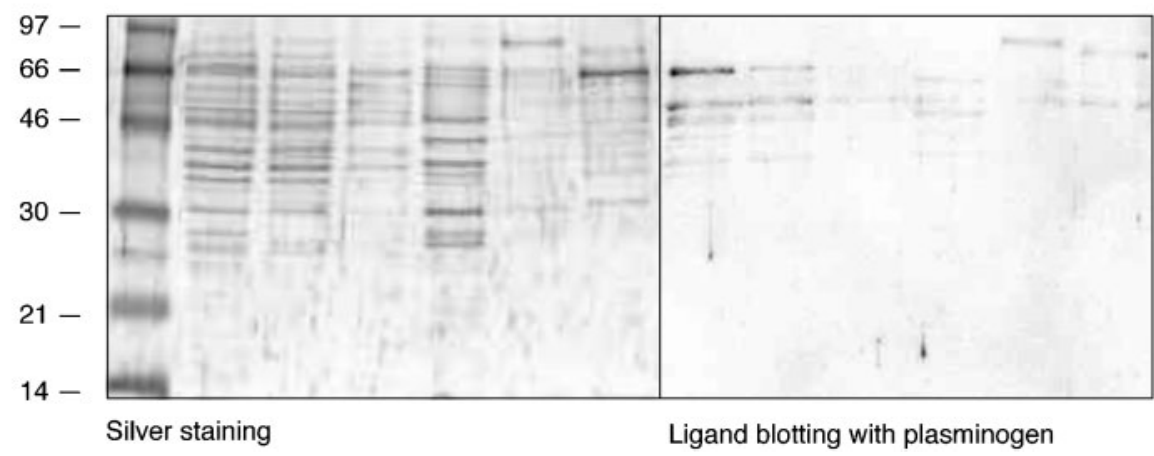

Fig. 3. Silver-stained and plasminogen-blotted SDS-PAGE gels of six strains of oral streptococci: (a) released proteins (b) cell-surface-associated proteins.

propanesulfonate treatment. Since the amount of protein applied in the SDS-PAGE was the same, it is apparent that only a fraction of the proteins produced and extruded from the bacteria are retained in or recaptured at the cell wall. This might mean that the capacity to recapture and attach released proteins to the cell surface could be the determining factor in the expression of a plasminogen-binding phenotype, thus providing the prerequisite for activation.

In order for bacteria to produce plasminogen-activating activity, different mechanisms can be employed (Lottenberg et al., 1994), such as taking advantage of the host organism's own plasminogen activators to activate host-derived plasminogen bound to the bacterial surface; or the microorganisms can produce their own plasminogen-activating substances. In either case, surface binding is crucial for reaching the required concentration of reactants. Streptokinase, a product of many streptococci, forms a complex with plasminogen whereby the structure is altered so that plasminogen gains plasmin activity without the need for proteolytic cleavage (Reddy \& Markus, 1972). On the other hand, micro-organisms such as Yersinia pestis have also been shown to produce a true proteolytic bacterial plasminogen activator (Sodeinde et al., 1988). The functional fibrinolytic assay on preformed fibrin gels showed that all of the strains in our study bound plasminogen that could be activated with or without the addition of any plasminogen activator. However, none of the bacteria exhibited inherent fibrin-degrading activity in the absence of plasminogen. Since the test strains had the ability to form plasmin from extracellular plasminogen without proteolytic activation by added plasminogen activator, activation is clearly a property of the streptococcal cells. Our results showed that all the tested strains produced streptokinase, which thus most likely was responsible for the plasminogen activation in the fibrinolysis assay. This finding is in agreement with those of Jones \& Holt (2004), who however interpreted their results with S. mutans M51 to be the effect of a plasminogen activator localized on the cell surface, although no evidence was provided for this being a genuine proteolytic plasminogen activator rather than a complex-former like streptokinase. Our present results demonstrate, we believe for the first time, the production of streptokinase by streptococci of oral origin.

Plasminogen binding is a virulence factor that facilitates tissue invasion and spread of bacteria (Boyle \& Lottenberg, 1997). The fact that all the commensal strains in the present study bound plasminogen and displayed plasminogen-activating activity suggests that, for these bacteria, 
(a)

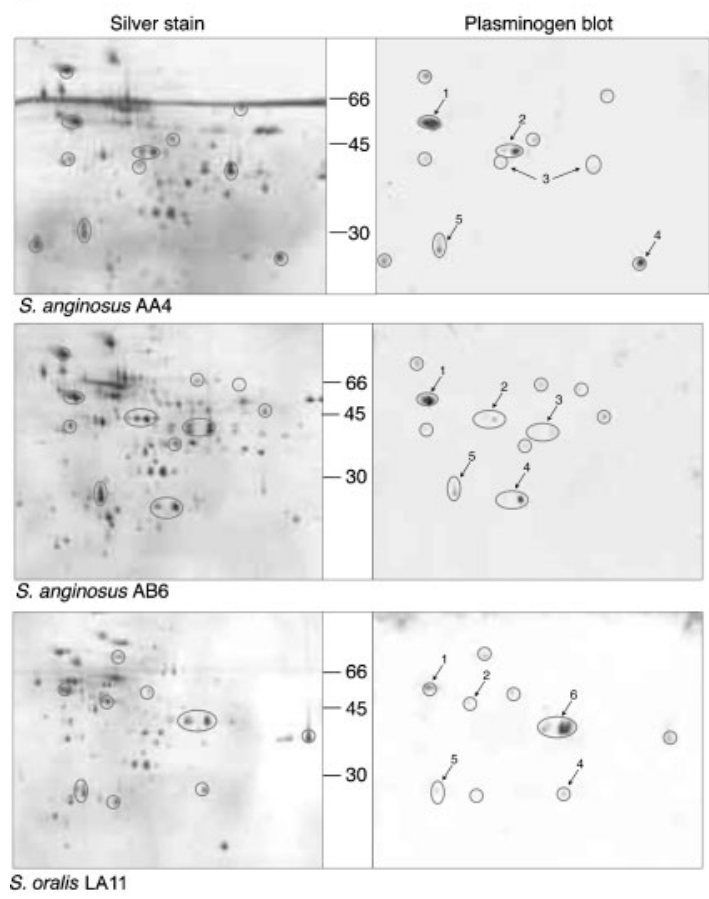

(b)
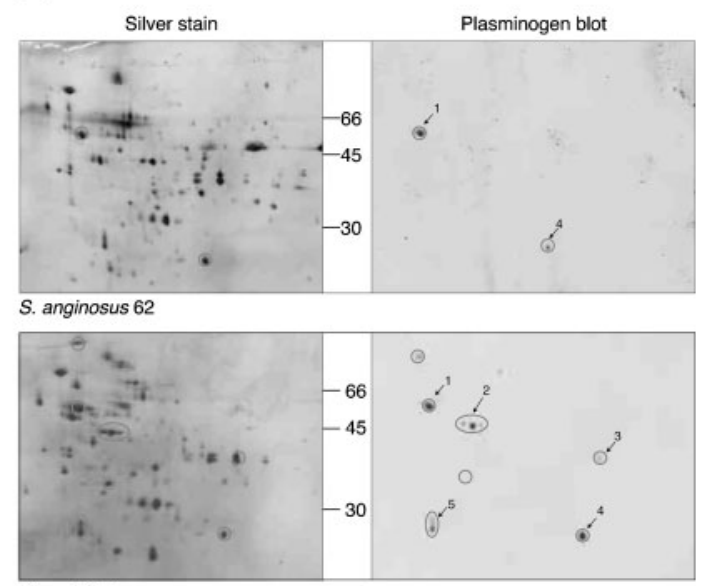

S. oralis 63

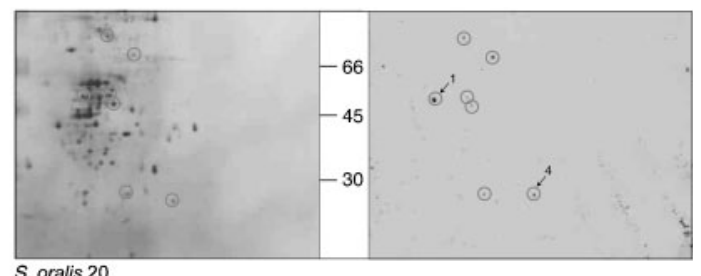

Fig. 4. $2 D E$ of released proteins from (a) three strains isolated from dental plaque, and (b) three strains of oral streptococci isolated from pus. The left panels show silver-stained gels, the right panels show ligand blots with human Glu-plasminogen. Plasminogen-binding spots are circled; numbered spots represent the following proteins: 1, enolase; 2, phosphoglycerate kinase; 3, glyceraldehyde-3-phosphate dehydrogenase; 4, phosphoglycerate mutase; 5, triosephosphate isomerase; 6, 6phosphofructokinase.

plasminogen binding may not necessarily be a virulence factor as suggested in other previous studies of bacteria of other origins. Rather, it may be regarded as a bacterial survival mechanism that prevents bacteria with bound plasminogen from becoming entrapped in a fibrin coagulum. The released plasminogen-binding proteins may aid in activating plasminogen, thereby contributing to the enlargment of the lesion, whereas only those proteins bound to the cell surface would be of physiological function in invasion and dissemination. No difference in plasminogen binding was found between bacteria from plaque and from pus. The results of the present study show that resident bacteria belonging to the normal oral flora irrespective of location bind plasminogen in a manner similar to highly pathogenic bacteria. Crowe et al. (2003) reported a similar result, showing that a non-pathogenic yeast exhibited a $K_{\mathrm{d}}$ value similar to that of the pathogen $C$. albicans. This raises the question whether plasminogen binding is always associated with virulence.

\section{ACKNOWLEDGEMENTS}

We wish to express our gratitude to Professor Mogens Kilian, University of Aarhus, Denmark, for performing identifications of the streptococci. We also wish to thank Ulla-Britt Larsson, Birgitta Lindberg and Agnethe Henriksson for excellent technical assistance throughout the course of this work. We are also indebted to Professor Emeritus Ian Hamilton, Winnipeg, Manitoba, Canada, for valuable discussions of the manuscript. This study was supported by the Crafoord Foundation, the Knowledge Foundation (KK-stiftelsen, Biofilms - Research Center for Biointerfaces), the Swedish Research Council (grant no. K2005-06X-12266-07A) and the British Heart Foundation. The proteomics analyses were performed by the Aberdeen Proteome Facility, which is funded jointly by SHEFC, BBSRC and the University of Aberdeen (UK).

\section{REFERENCES}

Boyle, M. D. \& Lottenberg, R. (1997). Plasminogen activation by invasive human pathogens. Thromb Haemost 77, 1-10.

Castellino, F. J. \& Violand, B. N. (1979). The fibrinolytic system basic considerations. Prog Cardiovasc Dis 21, 241-254.

Chavez de Paz, L., Svensäter, G., Dahlén, G. \& Bergenholtz, G. (2005). Streptococci from root canals in teeth with apical periodontitis receiving endodontic treatment. Oral Surg Oral Med Oral Pathol Oral Radiol Endod 100, 232-241.

Cole, J. N., Ramirez, R. D., Currie, B. J., Cordwell, S. J., Djordjevic, S. P. \& Walker, M. J. (2005). Surface analyses and immune reactivities of major cell wall-associated proteins of group a streptococcus. Infect Immun 73, 3137-3146.

Coleman, J. L. \& Benach, J. L. (1999). Use of the plasminogen activation system by microorganisms. J Lab Clin Med 134, 567-576. 
Coleman, J. L. \& Benach, J. L. (2000). The generation of enzymatically active plasmin on the surface of spirochetes. Methods 21, 133-141.

Coleman, J. L., Gebbia, J. A., Piesman, J., Degen, J. L., Bugge, T. H. \& Benach, J. L. (1997). Plasminogen is required for efficient dissemination of B. burgdorferi in ticks and for enhancement of spirochetemia in mice. Cell 89, 1111-1119.

Collen, D. (2001). Ham-Wasserman lecture: role of the plasminogen system in fibrin-homeostasis and tissue remodeling. Hematology (Am Soc Hematol Educ Program) 1-9.

Crowe, J. D., Sievwright, I. K., Auld, G. C., Moore, N. R., Gow, N. A. \& Booth, N. A. (2003). Candida albicans binds human plasminogen: identification of eight plasminogen-binding proteins. Mol Microbiol 47, 1637-1651.

Darenfed, H., Grenier, D. \& Mayrand, D. (1999). Acquisition of plasmin activity by Fusobacterium nucleatum subsp. nucleatum and potential contribution to tissue destruction during periodontitis. Infect Immun 67, 6439-6444.

Degen, J. L., Bugge, T. H. \& Goguen, J. D. (2007). Fibrin and fibrinolysis in infection and host defence. J Thromb Haemost 5 (Suppl. 1), 24-31.

Derbise, A., Song, Y. P., Parikh, S., Fischetti, V. A. \& Pancoli, V. (2004). Role of the C-terminal lysine residues of streptococcal surface enolase in Glu- and Lys-plasminogen-binding activities of group A streptococci. Infect Immun 72, 94-105.

Eberhard, T., Kronvall, G. \& Ullberg, M. (1999). Surface bound plasmin promotes migration of Streptococcus pneumoniae through reconstituted basement membranes. Microb Pathog 26, 175-181.

Grenier, D. \& Bouclin, R. (2006). Contribution of proteases and plasmin-acquired activity in migration of Peptostreptococcus micros through a reconstituted basement membrane. Oral Microbiol Immunol 21, 319-325.

Hasona, A., Zuobi-Hasona, K., Crowley, P. J., Abranches, J., Ruelf, M. A., Bleiweis, A. S. \& Brady, L. J. (2007). Membrane composition changes and physiological adaptation by Streptococcus mutans signal recognition particle pathway mutants. J Bacteriol 189, 1219-1230.

Hoshino, T., Fujiwara, T. \& Kilian, M. (2005). Use of phylogenetic and phenotypic analyses to identify non-hemolytic streptococci from bacteremic patients. J Clin Microbiol 43, 6073-6085.

Hughes, M. J., Moore, J. C., Lane, J. D., Wilson, R., Pribul, P. K., Younes, Z. N., Dobson, R. J., Everest, P., Reason, A. J. \& other authors (2002). Identification of major outer surface proteins of Streptococcus agalactiae. Infect Immun 70, 1254-1259.

Jones, M. N. \& Holt, R. G. (2004). Activation of plasminogen by Streptococcus mutans. Biochem Biophys Res Commun 322, 37-41.

Khil, J., Im, M., Heath, A., Ringdahl, U., Mundada, L., Engleberg, N. C. \& Fay, W. P. (2003). Plasminogen enhances virulence of group A streptococci by streptokinase-dependent and streptokinase-independent mechanisms. J Infect Dis 188, 497-505.

Kinnby, B. (2002). The plasminogen activating system in periodontal health and disease. Biol Chem 383, 85-92.

Kinnby, B., Lecander, I., Martinsson, G. \& Åstedt, B. (1991). Tissue plasminogen activator and placental plasminogen activator inhibitor in human gingival fluid. Fibrinolysis 5, 239-242.

Lähteenmäki, K., Edelman, S. \& Korhonen, T. K. (2005). Bacterial metastasis: the host plasminogen system in bacterial invasion. Trends Microbiol 13, 79-85.

Li, Z., Ploplis, V. A., French, E. L. \& Boyle, M. D. (1999). Interaction between group A streptococci and the plasmin(ogen) system promotes virulence in a mouse skin infection model. J Infect Dis 179, 907-914.

Lijnen, H. R. (2001). Plasmin and matrix metalloproteinases in vascular remodeling. Thromb Haemost 86, 324-333.
Ling, E., Feldman, G., Portnoi, M., Dagan, R., Overweg, K., Mulholland, F., Chalifa-Caspi, V., Wells, J. \& Mizrachi-Nebenzahl, Y. (2004). Glycolytic enzymes associated with the cell surface of Streptococcus pneumoniae are antigenic in humans and elicit protective immune responses in the mouse. Clin Exp Immunol 138, 290-298.

Lottenberg, R., Minning-Wenz, D. \& Boyle, M. D. (1994). Capturing host plasmin(ogen): a common mechanism for invasive pathogens? Trends Microbiol 2, 20-24.

Medved, L. V., Solovjov, D. A. \& Ingham, K. C. (1996). Domain structure, stability and interactions in streptokinase. Eur J Biochem 239, 333-339.

Pancholi, V. \& Fischetti, V. A. (1998). Enolase, a novel strong plasmin(ogen) binding protein on the surface of pathogenic streptococci. J Biol Chem 273, 14503-14515.

Perkins, D. N., Pappin, D. J. C., Creasy, D. M. \& Cottrell, J. S. (1999). Probability-based protein identification by searching sequence databases using mass spectrometry data. Electrophoresis 20, 3551-3567.

Plow, E. F., Herren, T., Redlitz, A., Miles, L. A. \& Hoover-Plow, J. L. (1995). The cell biology of the plasminogen system. FASEB J 9, 939-945.

Reddy, K. N. N. \& Markus, G. (1972). Mechanism of activation of human plasminogen by streptokinase. Presence of active center in streptokinase-plasminogen complex. J Biol Chem 247, 1683-1691.

Rudney, J. D. \& Chen, R. (2006). The vital status of human buccal epithelial cells and the bacteria associated with them. Arch Oral Biol 51, 291-298.

Rudney, J. D., Chen, R. \& Zhang, G. (2005). Streptococci dominate the diverse flora within buccal cells. J Dent Res 84, 1165-1171.

Sanderson-Smith, M. L., Dowton, M., Ranson, M. \& Walker, M. J. (2007). The plasminogen-binding group A streptococcal M proteinrelated protein Prp binds plasminogen via arginine and histidine residues. J Bacteriol 189, 1435-1440.

Sodeinde, O. A., Sample, A. K., Brubaker, R. R. \& Goguen, J. D. (1988). Plasminogen activator/coagulase gene of Yersinia pestis is responsible for degradation of plasmid-encoded outer membrane proteins. Infect Immun 56, 2749-2752.

Sun, H., Ringdahl, U., Homeister, J. W., Fay, W. P., Engleberg, N. C., Yang, A. Y., Rozek, L. S., Wang, X., Sjöbring, U. \& Ginsburg, D. (2004). Plasminogen is a critical host pathogenicity factor for group A streptococcal infection. Science 305, 1283-1286.

Svensäter, G., Welin, J., Wilkins, J. C., Beighton, D. \& Hamilton, I. R. (2001). Protein expression by planktonic and biofilm cells of Streptococcus mutans. FEMS Microbiol Lett 205, 139-146.

Titball, R. W. \& Oyston, P. C. F. (2007). A plague upon fibrin. Nat Med 13, 253-254.

Walker, M. J., McArthur, J. D., McKay, F. \& Ranson, M. (2005). Is plasminogen deployed as a Streptococcus pyogenes virulence factor? Trends Microbiol 13, 308-313.

Welin, J., Wilkins, J. C., Beighton, D. \& Svensäter, G. (2004). Protein expression by Streptococcus mutans during initial stage of biofilm formation. Appl Environ Microbiol 70, 3736-3741.

Wilkins, J. C., Beighton, D. \& Homer, K. A. (2003). Effect of acidic pH on expression of surface-associated proteins of Streptococcus oralis. Appl Environ Microbiol 69, 5290-5296.

Winram, S. B. \& Lottenberg, R. (1998). Site-directed mutagenesis of streptococcal plasmin receptor protein (Plr) identifies the C-terminal Lys334 as essential for plasmin binding, but mutation of the plr gene does not reduce plasmin binding to group A streptococci. Microbiology 144, 2025-2035.

Edited by: M. Kilian 